
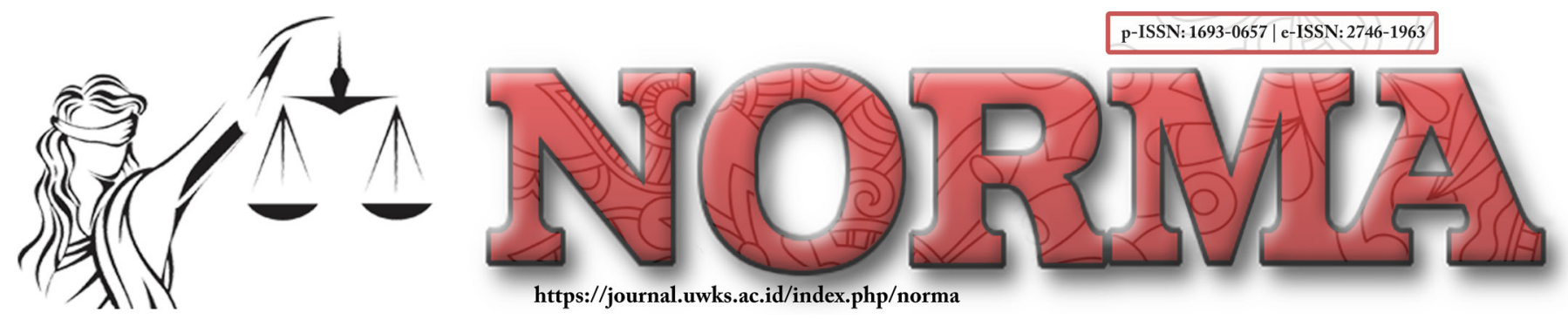

\title{
Legal Protection of Apartment Buyers Whose Land is Actually Being Secured with Hak Tanggungan
}

\author{
Karina Shandy Putri \\ Law Faculty, Universitas Airlangga \\ e-Mail: shandykarina@yahoo.com
}

\begin{abstract}
:
The study, entitled legal protection of apartment buyers whose land is actually being secured with Hak Tanggungan, first aims to find out and analyze how disputes are resolved for apartment buyers who experience law execution of their future Apartment units because the land rights are secured with Hak Tanggungan. This is normative legal research that will explore the contents of statutory regulations. The results of this research are that several instruments exist as a unit in purchasing an apartment/flats, one of which is PPJB, the status of the buyer is as a buyer, not bezitter, eignar, or non-litigation channels with specific steps prioritize detentor, the dispute settlement mechanism according to the Agreement in the PPJB. Following statutory regulations, however, the buyer can still take the litigation route as a mechanism for settling the dispute, with compensation claims and suit for default based on the existing PPJB.
\end{abstract}

Keywords: PPJB; Apartment; Hak Tanggungan.

Article's History:

Received:

February 16, 2021;

Peer-Reviewed:

February 24, 2021;

Accepted:

February 27, 2021;

Published:

March 5, 2021.

DOI:

10.30742/nlj.v18i1.1287

\section{INTRODUCTION}

The construction of apartment is an alternative solution to housing especially in urban areas where the population increases. Apartments' structure can reduce land use, making open urban spaces more spacious and optimally used as places. Terraced living that can accommodate as many people as possible. The construction of land-use optimization vertically to several levels will be more effective than horizontal. ${ }^{1}$

In an apartment building, some room can be owned individually and separately, which are called apartment units, and some features are joint rights of the apartment's unit owner. This common right includes common shares, everyday objects, and common land. Initially, the policy for building apartments in big cities in Indonesia was stated in various laws and regulations, including Law Number 16 of 1985 concerning Flats (from now on referred to as UURS), implemented by Government Regulation Number 41988 concerning Flats (from now on referred to as PPRS). ${ }^{2}$

${ }^{1}$ Urip Santoso, Hukum Perumahan (Jakarta: Kencana Media, 2016) 401.

2 Anggit Atma Yuwita, "Legal Action for Pre-Project Selling Based Buyers Whose Apartment Specification Have Changed Without Prior Approval" Norma. 17.3 (2021): 69. 
Developers as the party that can carry out apartments' structure require a lot of money to support the building's implementation. Therefore, developers usually apply for credit with guarantees to the bank. To increase the ability to build a apartment to the developer, a construction loan can be provided with the imposition of a Hak Tanggungan on the land to be used for the construction of apartments, which the credit has been approved can be paid in stages according to the value and results of these development developments, following the rules of Law Number 4 of 1996 concerning Hak Tanggungan (from now on referred to as UUHT). ${ }^{3}$

In terms of marketing carried out before the apartment's construction is carried out, everything promised by the developer and/or marketing agent is binding as a Sale and Purchase Agreement (from now on referred to as PPJB) for the parties. The process of buying and selling apartments before the construction of the apartments is completed can be done through PPJB, which is made in the presence of a notary. ${ }^{4}$ The sale and purchase of apartment units are carried out by pre-ordering the company to be purchased, outlined in the preliminary Agreement or deal and purchase Agreement, better known as PPJB. To secure the interests of sellers/developers and prospective buyers of apartment units. ${ }^{5}$ The PPJB function is as a preliminary agreement that aims to bind or bond the parties which contain provisions regarding the terms agreed upon in the main Agreement, namely the Sale and Purchase Deed (from now on referred to as AJB), which will later be drawn up in the presence of the Land Deed Making Official (from now on referred to as PPAT ). ${ }^{6}$

When the building is in the process of completing the construction of the apartments and several units of apartments have been sold with proof of PPJB ownership, in a situation where the developer does not pay the debt to the bank until it is due, the developer is considered to be in default because it cannot pay off the debt until it is due has been promised. The UUHT makes it easy for creditors to execute Hak Tanggungan rights if the debtor is in default, as regulated in Article 6 and Article 20 of the UUHT, that the bank as a creditor has the right to execute the object of the security right by selling it through a public auction according to the procedure specified in the regulation laws and regulations and collect the receivables from the sales proceeds. ${ }^{7}$

In conducting a public auction, a bank certainly cannot just carry it out; there must be clarity about the fate of the apartment unit buyers, especially for those who

${ }^{3}$ J. Satrio, Hukum Jaminan, Hak Jaminan Kebendaan, Hak Tanggungan, 1st ed. (Bandung: Citra Aditya Bakti, 2002) 136.

${ }^{4}$ Fani Martiawan Kumara Putra, "Characteristics of Notary Deeds for Transactions Through Electronic Media" NORMA. 17.3 (2021): 2.

${ }^{5}$ Tim Penulis Leks \& Co, Hukum Real Estate Bagian I Hukum Pertanahan, Perumahan dan Rumah Susun (Bandung: Citra Aditya Bakti, 2017) 41.

${ }^{6}$ Suriansyah Murhaini, Hukum Rumah Susun Eksistensi, Karakteristik, dan Pengaturan (Surabaya: Laksbang Grafika, 2015) 86.

7 Trisadini Prasastinah Usanti and Leonora Bakarbessy, Hukum Jaminan (Surabaya: Revka Petra, 2016) 105 . 
have made repayments for the sale and purchase of apartment units even though temporarily they only have PPJB as proof of legal ownership. Of course, this is a complicated problem related to the consequences of developer defaults on the buyers' fate and the efforts that buyers can make to execute the object of the Hak Tanggungan.

\section{RESEARCH METHOD}

This research is a normative legal research, which means that this research examines the legislation's side, not reading social symptoms due to existing legislation. This research's approach method is a statutory approach (statute approach) and conceptual approach. This approach is used because the discussion in this study will refer to the Law and the concept related to the issue..

\section{DISCUSSION}

Security rights over land are rights that reside with the creditor, which authorizes the creditor to sell land designated explicitly as collateral and collect the receivables from the sales proceeds if the debtor defaults or defaults. This authority is also accompanied by the right to repayment precedence over other creditors. In addition to granting Droit de preference, the security right to land will also burden the land used as collateral even though it is in whose hands the land is located (droit de suite). ${ }^{8}$

Article 4 of the UUHT states what things can be used as objects of insurance rights, namely:

a. Right of ownership;

b Cultivation Rights;

c. Building Use Rights over state land and land management rights;

d. According to the applicable provisions, use rights over State land must be registered and, according to its transferable nature, can also be burdened with security rights and land.

e. Ownership rights to apartment units standing on freehold land, building use rights over state land and land management rights, as well as usage rights over state land and land management rights;

f. Rights to land along with buildings, plants, and existing or future works that are an integral part of the land, and which are the property of the land rights holder whose imposition is expressly stated in the Deed of Granting Hak Tanggungan concerned, such as temples, statues, gate, relief that is one unit with the ground. ${ }^{9}$ As an accessory right, the birth of the Hak Tanggungan is based on the existence of a principal agreement, namely a debt-receivable agreement. ${ }^{10}$ Granting of Hak

${ }^{8}$ Boedi Harsono, Hukum Agraria Indonesia (Sejarah Pembentukan Undang-Undang Pokok Agraria, Isi dan Pelaksanaannya) (Jakarta: Djambatan, 1997) 328.

${ }^{9}$ Syahrani Riduan, Seluk Beluk dan Asas-Asas Hukum Perdata (Bandung: Alumni, 1992) 166.

${ }^{10}$ Kartini Muljadi, Hak Tanggungan (Jakarta: Kencana Media, 2005) 13. 
Tanggungan Rights is preceded by the debtor's promise to provide Hak Tanggungan Rights to creditors as collateral for debt repayment. ${ }^{11}$ This promise is set forth and is an integral part of the accounts payable Agreement. the relationship of the Agreement (privity of contract) between business actors (goods or services) and consumers, then the responsibility of business actors is based on Contractual Liability, namely civil liability based on agreements or contracts from business actors, for losses suffered by consumers as a result of consuming the goods it produces or utilizing the services it provides. The rights and obligations of the parties, especially the seller or developer, have been normatively regulated in several regulations, including in Articles 42, 43, and 44 of the UURS, which confirms: ${ }^{12}$

a. Developers can carry out marketing before the construction of the flat.

b. If the marketing is carried out before the construction of the apartment is carried out as referred to in paragraph (1), the construction actor must at least have:

1. The certainty of space allocation;

2. The certainty of land rights;

3. Confirmation of the tenure status of the apartment;

4. Flat construction permit; and

5. Guarantee for the construction of a flat from a guarantor institution.

c. Suppose marketing is carried out before the flat's construction, as referred to in paragraph (2). In that case, everything promised by the construction actor and/ or the marketing agent is binding as a sale and purchase binding Agreement (PPJB) for the parties.

Related to the PPJB implementation requirements:

a. The process of buying and selling apartment units before the construction is completed can be carried out through PPJB made in the presence of a notary.

b. PPJB, as referred to in paragraph (1), shall be conducted after meeting the certainty requirements:

1. Land ownership status;

2. IMB ownership;

3. Availability of infrastructure, facilities, public utilities;

4. Construction of at least $20 \%$ (twenty percent); and

5. The thing that was promised.

Related to the sale and purchase implementation:

a. The process of buying and selling carried out after the construction of a apartment is completed through AJB;

b. The construction of a apartment in the paragraph is complete as referred to in paragraph (1) if it has been published;

${ }^{11}$ Fani Martiawan Kumara Putra, “Tanggung Gugat Debitor Terhadap Hilangnya Hak Atas Tanah Dalam Obyek Jaminan Hak Tangggungan" Yuridika. 28.2 (2015): 130.

${ }^{12}$ Riduan, Seluk Beluk dan Asas-Asas Hukum Perdata 20. 
c. Certificate of eligibility to function;

d. SHM for a apartment unit or SKBG for a flat unit.

Requests for apartment units still in planning can occur at this time; the sale and purchase of apartment units when the apartment is still in the planning stage are carried out by pre-ordering the unit to be purchased, then stated in the PPJB. ${ }^{13}$ The binding of sale and purchase of apartment units may occur due to consumer demand to buy apartments that the developer has not completed. The Government explicitly regulates this in Kepmenpera No. 11 / KPTS / 1994; this regulation's legal consequence is that every sale and purchase Agreement on a apartment should follow Kepmenpera No. 11 / KPTS / 1994. The PPJB was made here due to several reasons, among others:

a. The certificate has not been issued on behalf of the seller and is still being processed at the Land Office;

b. The certificate has not been in the seller's name and is still in the process of turning over the name of the seller's name;

c. The certificate already exists and is in the name of the seller, but the buyer has not fully paid the sale and purchase price that has been agreed upon to the seller;

d. The certificate already exists, is in the name of the seller, and the price has been paid in full by the buyer to the seller, but the requirements are not yet complete;

e. The certificate was used as collateral at the bank. ${ }^{14}$

PPJB also contains the following:

1. The object to be traded

Apartments as objects to be bought and sold must have the necessary permits, such as location permits, proof of control and payment of land, and building permits.;

2. Management and Maintenance of Common Parts, Common Objects, and Common Land, which is the Obligation of All Residents

Prospective buyers of apartment units must be willing to become members of the Association of Owners and Occupants of Apartment Units (from now on referred to as PPPRS). The formation of PPPSRS has been regulated in Article 74 UURS and Article 54 PPRS;

\section{Developer Obligations}

Before carrying out the initial marketing, the developer is required to report initial marketing matters to the Mayor of the Level II Region with a copy to the State Minister for Public Housing If within a period of no later than 30 (thirty) calendar days as from the date stated in the receipt of the report there is no response from the relevant agency, the initial offering may be carried out.

${ }^{13}$ Eman Ramelan, Perlindungan Hukum Bagi Konsumen Pembeli Satuan Rumah Susun/Strata Titlel Apartemen (Yogyakarta: Aswaja Pressindo, 2015) 23.

${ }^{14}$ Ibid. 


\section{Obligations of the Orderer}

The subscriber is obliged to carry out all its obligations, both in the order letter and in the PPJB, and is subject to the terms and conditions of the PPPSRS articles of association and other related documents. After becoming a apartment buyer, every customer must pay a management fee and utility charge. ${ }^{15}$

Some experts say that PPJB holders are bezitters, but it is necessary to study further the existence of bezitter and eigenaar. Bezit controls or enjoys an object in a person's power personally or as an intermediary for another person as if the property belonged to him. Bezit which a person controls an object as if it were his own, protected by Law by not questioning whose actual ownership of the item is. Thus, for the existence of bezit, there must be two elements, namely power over an object and the willingness to own the item. If he meets the requirements as determined, he will get legal protection as a ruler (bezitter) without proving his rights. In the field of bezit, this principle does not apply to the control of immovable objects. ${ }^{16}$

In this case, bezit must be distinguished from "detentie," where a person controls an object based on a specific legal relationship with another person (the owner of the item). So, a "detentor" does not have the will to own the thing for himself. The definition of bezit is close to or almost the same as the definition of property rights (eigendom). The difference in eigendom shows more of a legal relationship between the owner and the object, whereas in bezit it shows a fundamental relationship between the owner and the item. Besides, in eigendom, a person can act as the owner (eigenaar) of an object because he is the owner.

The difference between eigendom rights and land rights is that eigendom rights are subject to $\mathrm{BW}$ originating from western Law. In contrast, land rights are subject to UUPA, which is derived from customary Law. Eigendom rights are broadly regulated in BW for all objects, both tangible and intangible. In contrast, ownership rights to land and other property rights over immovable objects regulated in the UUPA. ${ }^{17}$

So, it can be analyzed that the apartment unit buyer with PPJB ownership is deemed not to fulfill the characteristics of being a bezitter or eignaar. This is because to become a bezitter must meet several elements as regulated in Article 529 in conjunction with Article 1977 BW, and eignaar regulated in Article 570 BW. So, it can be concluded that the buyer's legal position is as a buyer as evidenced by a PPJB deed or can also be mentioned as a buyer in good faith.

Suppose there is an action that is detrimental to consumers. In that case, Article 21 UURS contains criminal sanctions for developers who violate Article 18 UURS (concerning the habitable permit and the building has been completed). So that

${ }^{15}$ Ibid., 42 .

${ }^{16}$ Moch Isnaeni, Pengantar Hukum Jaminan Kebendaan (Surabaya: Revka Petra, 2016$) 44$.

${ }^{17}$ Tan Thong Kie, Studi Notariat Dan Serba-Serbi Praktek Notaris (Jakarta: Ichtiar Baru Van Hoeve, 2013) 168. 
consumers can take criminal action against developers, but criminal sanctions are not what consumers expect. Consumers expect compensation for losses they have suffered if consumers can file claims for compensation based on default or illegal acts.

Suppose the buyer is going to file a suit for default. In that case, it is enough that he shows the Agreement that was violated through the PPJB made between the developer and the seller, and the developer will be burdened with evidence to state that there is no default. However, when going to file a lawsuit against the Law, the buyer must be ready to prove and demonstrate that not only is an act contrary to others' rights or contrary to his legal obligations, but there is also an element of error the developer. Regarding the claim for compensation requested, for default, the amount can indeed be estimated because it is in the Agreement. As for acts against the Law, it is up to the judge to assess the compensation amount.

In PPJB apartment units, the buyer does not yet have full rights to the sale object, a apartment unit. The buyer has full rights over the apartment unit if the sale and purchase deed has been signed so that consumers who have made installment payments on the object of sale and purchase can get legal certainty. The Agreement that the parties often carry out is currently a standard agreement; that is, the Agreement or clause cannot and cannot be negotiated or offered by other parties. ${ }^{18}$ This definitive Agreement tends to harm the less dominant party. In simple terms, a standard agreement has the following characteristics:

a. The Agreement is made unilaterally by producers whose position is relatively stronger than consumers;

b. Consumers are not at all involved in determining the contents of the Agreement;

c. Made in writing and bulk;

d. Consumers are forced to accept the contents of the Agreement because they are driven by necessity. ${ }^{19}$

PPJB implementation of apartment units must have legal protection for both the apartment unit buyer and the developer. Concerning the standard Agreement on the definitive Agreement, it can be seen that the business actor and the consumer have a legal agreement relationship, which by Law occurs when the sale and purchase transaction is carried out.

In the act of default, if the parties (both the developer and the buyer) interpret, then the parties who feel they have suffered a loss must prove the loss suffered. The occurrence of default in an agreement has consequences for the parties who do it. If the developer defaults, then the developer must compensate for the loss, the object which is the object of the engagement, since the default is the developer's responsibility, if the Agreement arises from a reciprocal arrangement, the buyer can request cancellation of

${ }^{18}$ Sutan Remy Sjahdeni, Kebebasan Berkontrak dan Perlindungan yang Seimbang Bagi Para PIhak dalam Perjanjian Kredit Bank di Indonesia, vols. (Jakarta: IBI, 1993).

${ }^{19} \mathrm{Ibid}$ 
the Agreement. Bankruptcy claims can be in the form of cancellation of the Agreement, the Agreement's fulfillment, payment of compensation, cancellation of the Agreement with bonus, the fulfillment of the Agreement with bonus, adjusted to the statutory regulations that govern the provisions. ${ }^{20}$

Legal protection and dispute resolution that has been regulated in the UURS, some of these provisions impose an obligation on the seller to meet technical, administrative, and civil requirements, with the threat of both administrative, civil and criminal sanctions. ${ }^{21}$ The legal protections provided by the PPJB as a manifestation of the Law which was formed by the buyer and the developer is stated in the provisions concerning Development and Delivery as contained in the PPJB, which generally confirms that the developer will physically and gradually hand over the apartment unit to the buyer no later than - by no later than 6 (six) months. Suppose the time limit has passed, but the developer is still unable to deliver the apartment unit. In that case, the developer will pay the buyer a fine of $1 \%$ (one percent) per day of the buying and selling price (before Value Added Tax), calculated from the first day after the period's expiration. In Article 5 paragraph (2), for the next 3 (three) months. ${ }^{22}$

Suppose 3 (three) months after the time limit has passed, and the developer is still unable to deliver the apartment unit. In that case, the buyer can cancel the Agreement, and the developer will return the sale and purchase price which the developer has received from the buyer provided that the buyer is required to provide all original receipts and notification letters regarding the cancellation to the developer at least 30 (thirty) days before the cancellation. Then the developer will return the money along with fines that must be paid by the developer on the day and date the buyer signs the cancellation document for the purchase of an apartment by the buyer.

The settlement of disputes regarding apartments is regulated in Article 105 UURS, namely:

1. The settlement of disputes in the apartment sector shall first be attempted based on deliberation to reach a consensus;

2. If a dispute settlement through deliberation to reach a consensus cannot be reached, the injured party may sue through a court that is within the public court or outside the court based on an option agreed by the parties to the dispute through alternative dispute resolution;

3. The settlement of disputes outside the court as referred to in paragraph (2) shall be carried out through arbitration, consultation, negotiation, mediation,

${ }^{20}$ Fani Martiawan Kumara Putra, “Eksistensi Kreditor Separatis Sebagai Pemohon Dalam Perkara Kepailitan" Perspektif. 19.1 (2014): 2.

${ }^{21}$ Andi Hamzah, I Wayan Suandara, and B.A. Manalu, Dasar-Dasar Hukum Perumahan (Jakarta: Rineka Cipta, 2006) 52.

${ }^{22}$ Ramelan, Perlindungan Hukum Bagi Konsumen Pembeli Satuan Rumah Susun/Strata Title/Apartemen 180. 
conciliation, and/or expert judgment following the provisions of laws and regulations;

4. As referred to in paragraph (3), disputes outside the court do not eliminate criminal responsibility.

In connection with this consumer dispute resolution, resolving disputes outside the court can be in the form of arbitration, consultation, negotiation, mediation, conciliation, and/or expert judgment. By this means, consumer disputes are resolved first by direct meetings between consumers and business actors or through third parties' assistance. ${ }^{23} \mathrm{~A}$ bargaining process occurs to resolve consumer disputes between business actors and consumers with consultation or negotiation. ${ }^{24}$

Third parties help the disputing parties find a settlement between them by utilizing arbitration, consultation, negotiation, mediation, conciliation, and/or experts. The third-party referred here is a neutral party, not taking sides with one of the dispute parties. The third party helps the parties find a solution. It is hoped that this deliberative settlement of disputes is intended to settle disputes between the parties, without using a legal attorney, so that answers to the problem can be found by peaceful means. ${ }^{25}$

As is well known, the model of civil dispute resolution in court or settlement through litigation is generally based on two basic patterns, namely:

a. The existence of default or broken promise of one of the parties, where for this lawsuit must be based on the presence of a contractual relationship (privity of contract) between the parties (plaintiff and defendant);

b. There is an act that violates the Law, wherein a lawsuit based on an unlawful act, there is no need to precede a contractual relationship between the parties. Still, the most elementary is that there is an act that harms the other party, and there is a causal relationship between the action and the losses incurred as a result of his mistake. ${ }^{26}$

If a claim is filed in court, the process or stages in examining the compensation claim will be questioned concerning the business actor's accountability. According to Article 48 of the UUPK, consumer dispute resolution through the courts refers to the general court's provisions.

\section{CLOSING}

\section{Conclusion}

Relying on PPJB, the apartment unit buyer is not yet the owner, as long as the property rights transfer has not been fulfilled. Buyers also cannot be classified as

${ }^{23}$ Yusuf Shofie, Penyelesaian Sengketa Konsumen Menurut Undang-Undang Perlindungan Konsumen (UUPK), Ed. Citra Aditya Bakti (Bandung, 2002) 35.

${ }^{24}$ Ibid., 37.

67.

${ }^{25}$ Jimmy J Sihombing, Cara Menyelesaikan Sengketa Di Luar Pengadilan (Jakarta: Visimedia, 2011)

${ }^{26}$ M. Abdul kadir, Hukum Acara Perdata Indonesia (Bandung: Citra Aditya Bakti, 1990) 28. 
bezitter, detenter, and eignaar. The dispute resolution mechanism can be carried out utilizing litigation and non-litigation by referring to existing regulations and referring to the agreed PPJB. Settlement through non-litigation channels is prioritized, with specific mechanisms agreed in the PPJB. The lawsuit filed by the buyer is a lawsuit for default because there is already an agreement between the developer and the buyer.

\section{Recommendation}

There is a need for increased supervision by the Government and related institutions concerning advertisements, standard agreement clauses, building quality standards, the importance of issuing certificates of legality standard for sale, and/or certificates of acceptance of function or the like as well as limiting the developer's authority in buying and selling apartment units if there is an opportunity for a violation. There must also be strict law enforcement for developer with bad faith.

\section{REFERENCES}

Atma Yuwita, Anggit. "Legal Action for Pre-Project Selling Based Buyers Whose Apartment Specification Have Changed Without Prior Approval." Norma 17.3 (2021): 69-79.

Hamzah, Andi, I Wayan Suandara, and B.A. Manalu. Dasar-Dasar Hukum Perumahan. Jakarta: Rineka Cipta, 2006.

Harsono, Boedi. Hukum Agraria Indonesia (Sejarah Pembentukan Undang-Undang Pokok Agraria, Isi dan Pelaksanaannya). Jakarta: Djambatan, 1997.

Isnaeni, Moch. Pengantar Hukum Jaminan Kebendaan. Surabaya: Revka Petra, 2016.

Kie, Tan Thong. Studi Notariat Dan Serba-Serbi Praktek Notaris. Jakarta: Ichtiar Baru Van Hoeve, 2013.

M. Abdul kadir. Hukum Acara Perdata Indonesia. Bandung: Citra Aditya Bakti, 1990.

Muljadi, Kartini. Hak Tanggungan. Jakarta: Kencana Media, 2005.

Murhaini, Suriansyah. Hukum Rumah Susun Eksistensi, Karakteristik, dan Pengaturan. Surabaya: Laksbang Grafika, 2015.

Putra, Fani Martiawan Kumara. "Characteristics of Notary Deeds for Transactions Through Electronic Media." NORMA 17.3 (2021): 1-14

- - -. "Eksistensi Kreditor Separatis Sebagai Pemohon Dalam Perkara Kepailitan." Perspektif 19.1 (2014): 1-19.

- - - "Tanggung Gugat Debitor Terhadap Hilangnya Hak Atas Tanah Dalam Obyek Jaminan Hak Tangggungan." Yuridika 28.2 (2015): 1-37. 
Ramelan, Eman. Perlindungan Hukum Bagi Konsumen Pembeli Satuan Rumah Susun/ Strata Title/Apartemen. Yogyakarta: Aswaja Pressindo, 2015.

Riduan, Syahrani. Seluk Beluk dan Asas-Asas Hukum Perdata. Bandung: Alumni, 1992.

Santoso, Urip. Hukum Perumahan. Jakarta: Kencana Media, 2016.

Satrio, J. Hukum Jaminan, Hak Jaminan Kebendaan, Hak Tanggungan. 1st ed. Bandung: Citra Aditya Bakti, 2002.

Shofie, Yusuf. Penyelesaian Sengketa Konsumen Menurut Undang-Undang Perlindungan Konsumen (UUPK). Ed. Citra Aditya Bakti. Bandung, 2002.

Sihombing, Jimmy J. Cara Menyelesaikan Sengketa Di Luar Pengadilan. Jakarta: Visimedia, 2011.

Sjahdeni, Sutan Remy. Kebebasan Berkontrak dan Perlindungan yang Seimbang Bagi Para PIhak dalam Perjanjian Kredit Bank di Indonesia. Jakarta: IBI, 1993.

Tim Penulis Leks \& Co. Hukum Real Estate Bagian I Hukum Pertanahan, Perumahan dan Rumah Susun. Bandung: Citra Aditya Bakti, 2017.

Usanti, Trisadini Prasastinah, and Leonora Bakarbessy. Hukum Jaminan. Surabaya: Revka Petra, 2016. 